JUANG: Jurnal Wahana Konseling (Vol. 4, No. 1, Maret 2021)

\title{
DAMPAK PENGGUNAAN HANDPHONE TERHADAP PERUBAHAN SIKAP SISWA DALAM BERINTERAKSI DI SMP NEGERI 5 PALEMBANG
}

\author{
Hendi Prasetyo $^{1}$, M. Ferdiansyah ${ }^{2}$, Endang Surtiyoni ${ }^{3}$ \\ Universitas PGRI Palembang ${ }^{1}$ \\ Email: hendiprasetyaklx150@gmail.com \\ Universitas PGRI Palembang ${ }^{2}$ \\ Email: ferdiansyah@gmail.com \\ Universitas PGRI Palembang ${ }^{3}$ \\ Email: endangsurtiyoni@gmail.com
}

\begin{abstract}
ABSTRAK
Latar belakang dilaksanakanya penelitian ini adalah kurangnya interaksi siswa di SMP Negeri 5 Palembang akibat dampak dari penggunaan handphone.Tujuan penelitian ini adalah untuk mengetahui dampak penggunaan handphone terhadap interaksi sosial pada siswa SMP Negeri 5 Palembang.Jenis penelitian ini adalah deskriptif kuantitatif dengan menggunakan rumus persentase.Hasil penelitian yang diperoleh dari pembagian angket kepada siswa menggunakan google form. Hasil penelitian ini adalah menunjukkan bahwa siswa cenderung memiliki tingkat pemakaian yang tinggi yaitu memiliki presentase 35,0 \% sampai $70 \%$. Sedangkan sikap siswa yang kurang memiliki rasa hormat kepada orang yang lebih tua yaitu menganggukkan kepala saat bertemu atau berpapasan dengan orang tua ditunjukkan dari tingkat presentase yang rendah hal ini terlihat pada jawaban responden memiliki presentase paling tinggi yaitu sebanyak 26 siswa atau 38,2 \%. Hal ini menunjukkan bahwa penggunaan handphone memiliki banyak dampak pada sikap interaksi siswa baik dengan teman ataupun dengan lingkungan sekitar.
\end{abstract}

Kata Kunci : Interaksi Siswa, Handphone

\section{THE IMPACT OF USING A HANDPHONE ON THE CHANGES OF ATTITUDES OF STUDENTS IN INTERACTING AT SMP NEGERI 5 PALEMBANG}

\begin{abstract}
The background of the implementation of this research is the interaction of students at SMP Negeri 5 Palembang the impact of using cellphones. The purpose of this study was to see the impact of cellphone use on social interaction among students of SMP Negeri 5 Palembang. This type of research is quantitative descriptive using the proportion formula. The results of the research were obtained from distributing questionnaires to students using the google form. The results of this study indicate that students tend to have a high level of usage, namely having a percentage of $35.0 \%$ to $70 \%$. While the attitude of students who
\end{abstract}


lacked respect for older people, namely nodding their heads when meeting or passing by their parents was shown from the low level of presentation, this can be seen in the respondents' answers having the highest presentation, namely 26 students or $38.2 \%$. This shows that the use of cellphones has many impacts on student interactions, both with friends and with the surrounding environment.

\section{Keywords: Student Interaction, Handphone}

\section{PENDAHULUAN}

Sejak pertangahan abad ke-20 hingga kini, dunia mengalami perkembangan teknologi yang sangat deras.Berbagai macam penemuan menghiasi kehidupan masyarakat modern.Keinginan dan ketidakpuasan merupakan salah satu faktor pendorong perubahan sosial terutama perubahan teknologi.Sebuah tekhnologi pada hakikatnya diciptakan untuk membuat hidup manusia menjadi semakin mudah dan nyaman. Kemajuan tekhnologi yang semakin pesat ini membuat hamper tidak ada bidang kehidupan manusia yang bebas dari penggunaanya, baik secara langsung maupun tidak langsung. Seiring arus globalisasi dengan tuntutan kebutuhan pertukaran informasi yang cepat, peranan tekhnologi komunikasi sangat penting.Salah satu kemajuan tekhnologi komunikasi tersebut adalah handphone.

Handphone merupakan salah satu bentuk pesatnya tekhnologi informasi.Banyak kemudahan dan manfaat yang diambil dari kemajuan teknologi handphone.Hampir semua masyarakat sebagai pengguna tekhnologi informasi dan komunikasi membuktikan bahwa kehidupan tidak dapat lepas dari peran tekhnologi informasi khususnya handphone.Pada awalnya handphone yang berfungsi mempermudah upaya interaksi antar individu kini berdampak sebaliknya. Penggunaan handphone kini lebih sering menghabiskan waktu untuk mengobrol bersama dengan anggota keluarga lain. Penggunaan handphone yang tidak terkontrol seperti inilah dapat menganggu proses interaksi soail (Lestari, dkk., 2018:205).

Selain itu, menurut Aziz dan Nurainiah (2018:21) menyatakan bahwa penggunaan handphone yang semakin berkembang di kalangan remaja ini, menimbulkan berbagai macam perubahan sikap dan perilaku di kalangan remaja 
itu sendiri. Dengan kebiasaan mereka yang lebih banyak menghabiskan waktu dengan berkomunikasi melalui handphone, otomatis waktu yang mereka gunakan untuk berinteraksi sosial secara langsung akan semakin berkurang.

Berdasarkan uraian di atas dapat diartikan bahwa penggunaan handphone secara berlebihan dan tidak tepat akan menjadikan sesorang tidak peduli pada lingkunganya baik dalam lingkungan keluarga maupun masyarakat. Hal ini dapat mengurangi sifat sosial manusia karena kecenderungan lebih suka berhubungan dengan internet dari pada bertemu langsung (tatap muka).Dari sisi sosial yang berubah dapat mengakibatkan perubahan pola masyarakat dalam berinteraksi.Manusia malas bersosialisasi dengan teman dan lingkunganya yang mengakibatkan seseorang dijauhi bahkan terasingkan di lingkungan sekitar.

Hasil pengamatan di SMP Negeri 5 Palembang ditemui bahwa penggunaan handphone di kalangan siswa telah menjamur rata-rata siswa memiliki handphone tentunya akibat penggunaan tersebut justru semakin banyak siswa yang mengalami perubahan interaksi sosial. Karena siswa lebih banyak menghabiskan waktunya dengan berkomunikasi melalui handphone secara otomatis waktu yang mereka gunakan untuk berinteraksi langsung akan berkurang.

Lebih lanjut, kualitas interaksi siswa yang berkurang akan membuat siswa menjadi hyperpersonal bahkan kurang pekanya dengan siswa terhadap lingkungan sekitar. Karena mereka terlalu sibuk menyendiri dengan handphonenya.Bahkan untuk menjalin silaturahmi secara face to face tidak lagi dilakukan, hanya orang tuanya saja yang selalu melakukan jalinan silaturahmi secara face to face. Penggunaan handphone di kelas juga dapat menganggu siswa dalam mengikuti proses pembelajaran sehingga kegiatan belajar mengajar menjadi kurang kondusif. Selain itu, dampak yang terlihat dari adanya kegiatan siswa yang banyak bermain handphone berupa game, menonton film di handphone dan sebagainya mengakibatkan nilai belajar mereka kurang memuaskan. Hal di atas menunjukkan bahwa masih rendahnya interaksi sosial akibat semakin maraknya penggunaan handphone sehingga tidak jarang pihak sekolah membuat dan menerapkan 
peraturan tata tertib yang melarang siswa membawa handphone pada saat proses pembelajaran dikelas.

Hal ini dikarenakan dapat mengganggu konsentrasi siswa dalam mengikuti proses pembelajaran. Selain itu, tujuan larangan siswa membawa handphone ini adalah membiasakan siswa untuk berinteraksi sosial dengan lingkungan.Guna menunjang hal tersebut dibutuhkan poeran serta guru Bimbingan dan Konseling untuk membantu, membimbing, mengarahkan siswa tersebut agar mampu mengurangi dampak negative dari penggunaan handphone dalam interaksi sosial siswa.Salah satu peran guru Bimbingan Konseling tersebut adalah pemberian layanan bimbingan konseling yakni layanan kelompok.Dengan layanan bimbingan kelompok ini diharapkan siswa dapat terlatih untuk berinteraksi sosial dengan teman sebayanya. Dengan demikian, siswa akan saling berinteraksi dengan baik, mampu menerima saran dan kritikan dari teman sebaya dan sebagainya.

Menurut Kamus Besar Bahasa Indonesia (KBBI Online, 2010) yang di maksud dengan dampak adalah pengaruh kuat yang mendatangkan akibat (baik positif maupun negatif). Adapun pengertian pengaruh sendiri seperti yang dipaparkan beberapa ahli yakni: Pengaruh adalah daya yang ada atau timbul dari sesuatu (orang, benda) yang ikut membentuk watak, kepercayaan atau perbuatan seseorang. Senada dengan Purwadarminta yang mendefinisikan pengaruh sebagai sebuah daya yang ada atau yang timbul dari sesuatu (orang, benda dan sebagainya) yang berkuasa atau yang berkekuatan (gaib dan sebagainya). Sehingga bagi beberapa ahli pengaruh merupakan segala hal baik itu benda atau pun manusia serta apa pun yang mana atas hal-hal tersebut dapat membentuk karakter, keyakinan atau perilaku seseorang.

Dampak secara sederhana bisa diartikan sebagai pengaruh atau akibat.Dalam setiap keputusan yang diambil oleh seorang atasan biasanya mempunyai dampak tersendiri, baik itu dampak positif maupun dampak negatif. Dampak juga bisa merupakan proses lanjutan dari sebuah pelaksanaan pengawasan internal. 


\section{LANDASAN TEORI}

Komunikasi merupakan suatu proses pengiriman dan penerimaan informasi atau pesan dari komunikator kepada komunikan baik secara verbal maupun non verbal (Fauzy, 2019:151). Selain itu, Liliweri (2014:3) Menyatakan bahwa komunikasi merupakan suatu rangkaian proses pengalihan informasi dengan menggunakan symbol verbal atau non verbal dari satu orang kepada orang lain.

Penggunaan handphone tergolong dalam komunikasi massa. Karena komunikasi tersebut menggunakan saluran media dalam menghubungkan komunikator dan komunikan guna menyampaikan suatu pesan.

Handphone adalah sebuah perangkat telekomunikasi elektronik yang mempunyai kemampuan dasar yang sama dengan telepon fixed line sehingga konvensional namun dapat dibawa kemana-mana (portable) dan tidak perlu disambungkan dengan jaringan telepon kabel (nirkabel, wireless) (Efrozi, 2014:2). Hal yang berbeda diungkapkan oleh Sulandjari (2018:2) menyatakan bahwa handphone merupakan suatu alat elektronik yang digunakan untuk telekomunikasi radio dua arah melalui jaringan selular BTS yang dikenal sebagai situs selo.

Handphone dapat diartikan sebagai suatu perangkat telekomunikasi elektronik dua arah melalui jaringan seluler sebagai alat komunikasi yang dipergunakan untuk mendapatkan informasi.

Penggunaan handphone dapat membawa dampak tertentu.Dampak tersebut dibagi pada aspek psikologis, sosial, keuangan dan kesehatan atau kesematan jiwa seseorang (Aziz dan Nurainiah, 2018:10). Dari keempat dampak tersebut, maka dalam penelitian ini akan di bahas hanya dampak handphone pada aspek sosial, salah satu hal yang sering terjadi adalah tindakan seseorang membiarkan Smartphone miliknya tetap dalam keadaan hidup atau aktif sehingga mengeluarkan bunyi yang nyaring. Hal ini jelas mengganggu konsentrasi serta mengejutkan orang-orang disekitarnya.

Dampak penggunaan handphone dapat terjadi pada berbagai aspek yang dapat memepengaruhi kehidupan sosial bahkan kesehatan dan keuangan. 
Interaksi sosial adalah hubungan antara individu satu dengan individu yang lain yang dapat mempengaruhi individu yang lain atau sebaliknya (Walgito, 2003:65). Selain itu, Thibaut dan Kelly dalam Sarwono (2011:33) menyatakan bahwa interaksi sosial merupakan suatu hubungan antara dua orang atau lebih yang ditandai adanya saling tergantung antar sama lain untuk mencapai hasil-hasil yang positif yakni seperti terjalinya persahabatan dan kerjasama.

Interaksi sosial merupakan suatu hubungan antara individu satu dengan individu yang lain yang dapat mempengaruhi individu yang lain yang satu mempengaruhi, mengubah, atau memperbaiki kelakuan individu yang lain atau sebaliknya.

Menurut Arsori (2008:108) membagi tiga jenis interaksi, yakni interaksi verbal, interaksi fisik dan interaksi emosional. Selain itu, menurut Adang dan Anwar (2013:52) membedakan bentuk interaksi sosial menjadi beberapa bentuk interaksi sosial yang berkaitan dengan proses asosiatif, proses disosiatif, proses terjadinya serta interaksi emosional. Berdasarkan uraian di atas dapat diartikan bahwa secara garis besarnya bentuk interaksi sosial menjadi beberapa bentuk, yaitu: a) bentuk interaksi sosial yang berkaitan dengan proses asosiatif, b) bentuk interaksi sosial yang berkaitan dengan proses disosiatif, c) bentuk proses sosial menurut jumlaah perlakuanya, dan d) bentuk interaksi sosial menurut proses terjadinya.

Menurut Ahmadi (2009:52) mengatakan bahwa faktor yang mempengaruhi seseorang untuk melakukan interaksi sosial terdiri dari empat, yaitu: 1) imitasi, 2) sugesti, 3) identifikasi, 4) simpati. Hal ini juga sama dengan pendapat Dayaksini dan Hudaniah (2012:106) menyatakan bahwa ada beberapa faktor yang mempengaruhi interaksi sosial antara lain: 1) imitasi, 2) sugesti, 3) identifikasi, 4) simpati.

Jadi Faktor-Faktor yang mempengaruhi interaksi sosial menurut peneliti adalah proses dimana seseorang individu menerima suatu cara penglihatan atau pedoman-pedoman tingkah laku dari orang lain tanpa kritik terlebih dahulu. 


\section{METODE PENELITIAN}

Penelitian ini merupakan jenis deskriptif korelasional.Penelitian deskriptif korelasional dapat memastikan berapa besar pengaruh yang disebabkan oleh satu variabel dalam hubungannya dengan variasi yang disebabkan oleh variabel lain (Rakhmat, 2005:33).Pendekatan penelitian adalah kuantitatif.Data yang digunakan dalam penelitian adalah data kuantitatif yang didukung oleh data kualitatif.Data kuantitatif dilakukan dengan metode survei, yaitu melalui kuisioner sebagai instrumen utama penelitian.Sedangkan data kualitatif sebagai pendukung penelitian melalui wawancara untuk mendapatkan keterangan tambahan dariresponden.Hal ini bertujuan untuk mengetahui dampak penggunaan handphone terhadap interaksi sosial pada siswa SMP Negeri 5 Palembang.

Observasi adalah pengamatan secara langsung dan pencatatan sistematis terhadap objek yang diteliti untuk mendapatkan data-data mengenai perilaku siswa/siswi (Husaini Usman 2008:52) di SMP Negeri 5 Palembang.

Dari pengertian instrument tersebut dapat diketahui bahwa instrument penelitian digunakan untuk melakukan pengukuran dengan tujuan menghasilkan data yang akurat.Sasaran pemeberian angket ini adalah siswa kelas VIII di SMP Negeri 5 Palembang. Skala yang digunakan dalam penelitian ini yaitu skala likert menurut Sugiyono (2019 : 186) "skala Likert digunakan untuk mengukur sikap, pendapat dan persepsi seseorang atau sekelompok orang tentang fenomena sosial".

\section{HASIL DAN PEMBAHASAN}

Handphone merupakan sebuah inovasi dari teknologi terbaru dengan kemampuan yang lebih baik dan fitur terbaru yang memiliki tujuan maupun fungsi lebih praktis dan juga lebih berguna.Dari banyaknya handphone yang diciptakan, salah satu jenis handphone yang paling akrab dalam kehidupan seharihari adalah ponsel cerdas. Seiring dengan perkembangan teknologi, telepon selular juga mengalami beberapa tambahan fitur-fitur seperti PDA (Personal Digital Assistant), kamera digital, pemutar multimedia, akses internet, client untuk email, dan pesan instan, bahkan penyedia perangkat lunak perkantoran. 
Remaja merupakan kelompok manusia yang penuh potensi yang perlu untuk dimanfaatkan. Secara psikologis, usia remaja adalah usia di mana individu berintegrasi dengan masyarakat dewasa, usia di mana anak tidak lagi merasa di bawah tingkat orang-orang yang lebih tua melainkan berada dalam tingkat yang sama. Penggunaan smartphone yang semakin berkembang di kalangan remaja ini, menimbulkan berbagai macam perubahan sikap dan perilaku di kalangan remaja itu sendiri.Remaja lebih memilih untuk berkomunikasi dengan teman-teman yang berada dalam satu komunitas pengguna smartphone daripada berkomunikasi dengan teman yang ada di sebelahnya. Kecenderungan ini merupakan kondisi yang memprihatinkan karena ditinjau dari usia sekolah, di usia yang masih labil mereka seharusnya terbiasa untuk bergaul dan berkomunikasi secara langsung dengan teman atau orang lain di lingkungan sosialnya. Dengan kebiasaan mereka yang lebih banyak menghabiskan waktunya dengan berkomunikasi melalui handphone, otomatis waktu yang mereka gunakan untuk berinteraksi secara langsung akan berkurang.

Dalam penelitian ini yang menjadi responden dalam pengumpulan data wawancara adalah beberapa siswa VIII SMP Negeri 5 Palembang melalui video call/Telphone.Responden menyatakan selama Pendemi ini banyak menggunakan handphone baik untuk belajar daring ataupun hanya bermain sosial media bahkan hanya untuk bermain game, selain itu handphone dijadikan alat untuk berinteraksi sesama guru dan teman sekola. Hal ini menunjukkan bahwa sebagian siswa menggunakan handphone untuk berinteraksi dan berkomunikasi dengan seseorang lewat media sosial seperti sms, facebook, whatshap, instagram yang dapat menyebabkan perubahan sikap sosial terhadap lingkunganya.

Berdasarkan hasil penelitian yang dilakukan dan di jabarkan diatas data yang dihasilkan dari responden dengan indicator Kepemilikan atau kepentingan terhadap handphone. Responden cenderung memiliki tingkat pemakaian yang tinggi misalnya responden menggunakan handphone untuk menelpon, mengirim SMS, bermain game atau bahkan hanya membawanya setiap hari memiliki presentase $35,0 \%$ sampai $70 \%$. Berdasarkan tabel 4.3 dapat diketahui bahwa pernyataan terbanyak yaitu sering 25 responden atau $36,8 \%$ dan pada Pada tabel 
4.5 menunjukkan bahwa jawaban responden dari pernyataan selalu memiliki presentase paling tinggi yaitu sebanyak 27 siswa atau 39,7 \%, dan pernyataan dengan jawaban tidak pernah memliki presentase $0 \%$ hal ini menunjukkan bahwa siswa mengoperasikan handphone setiap hari dari hasil yang didapatkan bahwa penggunaan handphone dikalangan remaja mempunyai tingkat presentase yang tinggi.

Pemanfaatan handphone secara positif misalnya menggunakan handphone untuk mendapatkan informasi atau pengetahuan khususnya dalam bidak teknologi mempunyai presentase $100 \%$ yang berarti responden menyadari banyak manfaat yang didapatkan dalam penggunaan handphone namun tidak sedikit responden memanfaatkan handphone secara negative misalnya menggunakan handphoneuntuk bermain game sampai lupa waktu bahkan dalam jam belajar masih menggunakan untuk mendengarkan musik dan tukar menukar jawaban saat ujian ini beberapa contoh pemanfaatan handphone sebagai media pembelajaran secara negatife.

Penggunaan handphone sangat berpengaruh terhadap interaksi sosial misalnya dalam Perilaku siswa di lingkungan sekitar dan lingkungan sekolah pada tabel 4.8 menjelaskan bahwa jawaban responden dari pernyataan selalu memiliki presentase paling tinggi yaitu sebanyak 30 siswa atau $44,1 \%$, dan pernyataan dengan jawaban tidak pernah memliki presentase $0 \%$ hal ini menunjukkan bahwa siswa sering berjalan tegak memperhatikan lingkungan disekitar. Perilaku siswa terhadap teman sebaya, guru dan orang lain dan Perilaku siswa dalam kelas ketika proses pembelajaran mempunyai tingkat presentase yang tinggi yaitu pada tabel 4.25 menunjukkan bahwa jawaban responden dari pernyataan selalu memiliki presentase paling tinggi yaitu sebanyak 28 siswa atau 41,1\%, hal ini menunjukkan bahwa rata-rata siswa masih berinteraksi dengan teman saat jam istirahat di sekolah dan Pada tabel 4.27 di atas menunjukkan bahwa siswa cenderung menggunakan handpone saat pada saat jam kosong hal ini ditunjukkan pada jawaban responden dari pernyataan sering memiliki presentase paling tinggi yaitu sebanyak 22 siswa atau 32,3\%, pernyataan dengan jawaban selalu memiliki presentase 18 siswa atau 26,5\% dan pernyataan dengan jawaban tidak pernah 
memliki presentase sebanyak 5 atau 7,35 \% yang berarti siswa sering bahkan selalu mengunakan handphone pada saat jam kosong sedangkan Pada tabel 4.15 menunjukkan bahwa jawaban responden dari pernyataan jarang memiliki presentase paling tinggi yaitu sebanyak 26 siswa atau 38,2 \%, dan pernyataan dengan jawaban selalu memliki presentase sebanyak 3 siswa atau 4,4 \% hal ini menunjukkan bahwa banyak siswa yang kurang memiliki rasa hormat kepada orang yang lebih tua yaitu menganggukkan kepala saat bertemu atau berpapasan dengan orang tua ditunjukkan dari tingkat presentase yang rendah.

\section{KESIMPULAN}

Dari hasil penelitian dan pembahasan yang dilakukan oleh peneliti di SMP Negeri 5 Palembang menarik kesimpulan sebagai berikut:

1. Penggunaan handphone dalam kalangan siswa SMP Negeri 5 Palembang sangat berpengaruh pada interaksi sosial mereka baik pengaruh negative maupun pengaruh positif.

2. Siswa cenderung memiliki tingkat pemakaian yang tinggi misalnya responden menggunakan handphone untuk menelpon, mengirim SMS, bermain game atau bahkan hanya membawanya setiap hari memiliki presentase 35,0\% sampai $70 \%$. Berdasarkan tabel 4.3 dapat diketahui bahwa pernyataan terbanyak yaitu sering 25 responden atau $36,8 \%$.

3. Siswa cenderung menggunkan handphone saat jam kosong hal ini ditunjukkan pada jawaban responden dari pernyataan sering memiliki presentase paling tinggi yaitu sebanyak 22 siswa atau 32,3\%, pernyataan dengan jawaban selalu memiliki presentase 18 siswa atau 26,5\% dan pernyataan dengan jawaban tidak pernah memliki presentase sebanyak 5 atau 7,35\% yang berarti siswa sering bahkan selalu mengunakan handphone pada saat jam kosong dan banyak siswa yang kurang memiliki rasa hormat kepada orang yang lebih tua yaitu menganggukkan kepala saat bertemu atau berpapasan dengan orang tua ditunjukkan dari tingkat presentase yang rendah hal ini terlihat pada jawaban responden dari pernyataan jarang memiliki 
presentase paling tinggi yaitu sebanyak 26 siswa atau 38,2 \%, dan pernyataan dengan jawaban selalu memliki presentase sebanyak 3 siswa atau 4,4\%.

\section{DAFTAR PUSTAKA}

Adang dan Anwar Yesmil. 2013. Sosiologi untuk Universitas. Bandung: Refika Aditama.

Ahmadi, Abu. 2009. Psikologi Sosial. Jakarta: Rineka Cipta.

Asrori, Mohammad. 2008. Psikologi Pembelajaran. Bandung: Wacana Prima

Aziz Muchlis dan Nurainiah.2018. Pengaruh Penggunaan Handphone terhadap Interksi Sosial Remaja di Desa Dayah Meunara Kecamatan Kutamakmur Kabupaten Aceh Utara.Jurnal Al-Ijtimaiyyah. Vol 4 No 1, Januari-Juni 2018.

Efrozi, dkk. 2014. Manfaat Handphone (HP) sebagai Media Pembelajaran. Makalah Ilmiah. Universitas Bengkulu: Program S2 Teknologi Pendidikan Fakultas Keguruan dan Ilmu Pendidikan.

Fauzy, Tati. 2019. Psikologi Konseling. Tanggerang: TS Mart.

Lestari, Indah, dkk. 2018. Pengaruh Gadget pada Interaksi Sosial dalam Keluarga.Prosding KS: Riset\& PKM Vol 2 No 2 Hal 147-300. ISSN : 24424480.

Liliweri, Alo. 2013. Dasar-dasar Komunikasi Kesehatan. Yogyakarta: Pustaka Belajar.

Sarwono, Sarlito W. 2011. Pengantar Psikologi Umum. Jakarta: Raja Grafindo Persada.

Sugiyono. 2019. Metode Penelitian Kuantitatif, Kualitatif, dan R\&D. Bandung : Alfabeta.

Sulandjari Rekno. 2018. Efektifitas Literasi Media (Video) dari Handphone Mahasiswa pada Minat Berwirausaha akanan Berbahan Baku Lele Berorientasi B2SA Masyarakat Desa Karangsari. Jurnal Egaliter Vol 1 No 2 Maret 2018.

Walgito, Bimo. 2003. Psikologi Sosial. Yogyakarta: Andi Offset. 